Article

\title{
A Critical Pragmatism: Marcuse, Adorno, and Peirce on the Artificial Stagnation of Individual and Social Development in Advanced Industrial Societies
}

Clancy Smith

\section{Introduction}

dvanced industrial societies offer a wide array of amenities, pleasures and luxuries to complement a technological substructure that has 1 invigorated myriad advances in all walks of life. Yet, this substructure has become so pervasive as to become "invisible," 1 receding into the gestalt of our human experience, and rarely questioned. For, as Marcuse queried, why should we question that which staves off disease, permeates our lives with pleasures, and appears to dissolve the once overpowering class structures that caused such sorrow and strife for so many? "If the individuals are satisfied to the point of happiness with the goods and services handed down to them by the administration...and if the individuals are pre-conditioned so that the satisfying goods also include thoughts, feelings, aspirations, why should they wish to think, feel and imagine for themselves?" 2 As initially beneficent as the structure of advanced industrial society appears, it has in place, most ingeniously, a self-perpetuating mechanism that not only allows it to endure, relatively unaltered, but undermines the means of questioning that very structure. Advanced industrial society has become uncritical of itself, allowing those foundations and that structure to remain unexamined. As a result, individual human autonomy gives way to a society-wide heteronomy. False needs, artificially constructed by the institutions and imposed upon the

1 The term "invisible" is useful in describing that which recedes into the unproblematic, non-reflective "gestalt" of our experience. William James took note of this phenomenon in his Principles of Psychology but it has also been utilized in a wide array of philosophical arenas, from the unnoticed and unearned white privilege, the "invisible knapsack," as noted by Peggy McIntosh in "White Privilege and Male Privilege: A Personal Account of Coming to See Correspondences through Work in Women's Studies" to the description of the unnoticed "habits" effecting Patricius, Augustine's father, in the Confessions, an "invisible wine" motivating his somewhat lascivious lifestyle.

${ }^{2}$ Herbert Marcuse, One-Dimensional Man (Boston: The Beacon Press, 1991), 50. 
populace as a means to advance their agendas, masquerade as true needs. Because the advanced industrial society has become "one-dimensional," that is, uncritical of itself, these false needs appear to be true needs, a conflation which has devastating ramifications for the development of the individuals within such a society. This self-perpetuating, "totalitarian"3 structure leads to a "one-dimensional society" and, moreover, a one-dimensional individual whose autonomy has been minimized and, subsequently, whose freedom for openended development has become artificially constrained and ultimately stagnated. This paper will analyze the effects advanced industrial societies have on individual and social development through the eyes of Marcuse's OneDimensional Man and the moral consequences of such artificial stagnation through Adorno's lectures on The Problems of Moral Philosophy. Because such an investigation necessarily brings us into the realm of social psychology, we will turn to the social psychological tradition at the heart of American pragmatism, a target for critical theorists who are often antagonistic to the entire tradition. We will endeavor to advance two alternate readings of the work of C.S. Peirce, arguing that although one type of pragmatism may be justly attacked by critical theorists, there is another, I argue, more critical manifestation of pragmatic human development, that requires the type of autonomy-infused, open-ended development that Marcuse champions. Moreover, I will argue that Peirce's seminal essay "The Fixation of Belief" anticipated many of Marcuse's critiques of advanced industrial societies by nearly ninety years.

\section{Part I: One-Dimensionality in Advanced Industrial Societies}

"By the 1950's, Marcuse...perceived that the unparalleled affluence of the consumer society and the apparatus of planning and management in advanced capitalism had produced new forms of social administration and a 'society without opposition' that threatened individuality and that closed off possibilities of radical social change," 4 notes Douglas Kellner in the introduction to the second edition of Herbert Marcuse's One-Dimensional Man. The scathing critique of advanced industrial societies forwarded by Marcuse highlighted the unique composition of the technological epoch, societies that perpetuate their own structures through processes of media control, institutionalized desublimation, and the artificial creation of false needs in their citizens. In short, Marcuse's critique emphasized the dominating role that an advanced industrial society has over its citizens, up to the point of dominating and controlling their very needs and desires and, subsequently, the very ways in which they develop. We will explore these components in turn; the artificial creation of false needs and the controlled institutionalized desublimation in culture and human development. The underlying theme that we will attempt to excavate is that these aspects (and by no means an exhaustive list) of advanced industrial societies serve to not only perpetuate the structure of said

\footnotetext{
${ }^{3}$ Ibid., 3.

${ }^{4}$ Ibid., xxv.
} 


\section{A CRITICAL PRAGMATISM}

societies, but also to artificially stagnate individual and social development while immunizing itself against critique. It is only through such an excavation that critique once again becomes a live possibility and, subsequently, reintroduces the possibility of freeing human development towards an openended future.

"If the individuals find themselves in the things which shape their life, they do so, not by giving, but by accepting the law of things - not the law of physics but the law of their society." 5 To "give" the law of things would be to demonstrate the type of autonomy so prized in Kant's moral theory and reimagined in Sartre's existentialism to which Marcuse refers frequently throughout the text. Autonomy would therefore be a "self-governing" as opposed to the heteronomy ${ }^{6}$ suggested here lying at the heart of advanced industrial societies in which individuals find themselves shaped by the things in their society rather than taking an active role in shaping themselves. Consider Marcuse's distinction between true and false needs.

False are those which are superimposed upon the individual by particular social interests in his repression: the needs which perpetuate toil, aggressiveness, misery and injustice. Their satisfaction might be more gratifying to the individual, but this happiness is not a condition which has to be maintained and protected if it serves to arrest the development of the ability (his own and others) to recognize the disease of the whole and grasp the chances of curing the disease. The result then is euphoria in unhappiness. ${ }^{7}$

What can it mean to have a "superimposed" need? Needs, by nature, well up from within the individual's consciousness reflecting some sort of lack that "needs" to be fulfilled. For a need to be superimposed is a subtle notion, indeed, for as all needs, "false," superimposed needs included, well up from within the individual's consciousness. The superimposition happens at a far more basic, primal level, a superimposition of false needs that arise within, and well up from, an individual's consciousness as if they were true, non-superimposed needs. And this is the crucial point, something indicative of many aspects of advanced industrial societies: the perpetration and perpetuation of the structures of the system go unnoticed, passing as if they were the natural discourse, the natural order, of events. By doing so, Marcuse notes, advanced industrial societies guard themselves against critique (for there appears there is nothing amiss that needs to be critiqued if false needs pass as true needs and what is artificial and superimposed passes as natural and good, especially when

\footnotetext{
${ }^{5}$ Ibid., 11

6 "The development and satisfaction of these needs is heteronymous," Ibid., 5.

${ }^{7}$ Ibid., 4-5.
} 
a genuine sort of euphoria is the result). As Marcuse himself notes above, it arrests the "development of the ability...to recognize the disease."

"Most of the prevailing needs to relax, to have fun, to behave and consume in accordance with the advertisements, to love and hate what others love and hate, belong to this category of false needs." 8 As appropriate an observation as this may have been in the sixties, its relevance has blossomed proportionately into the twenty-first century. The barrage of advertisements contemporary society endures is nearly beyond belief; ubiquitous billboards, commercials on radio and television, in movie theaters prior to the main attraction, and every webpage on computers and hand-held portable devices. We are inundated with such advertisements, instilling needs in us that were not there before, needs superimposed upon us not in isolation from our fellow man but in accord with him, what they love, what is popular, what must be had, is constantly changing, in a protean universe of needs not of our own making. Advanced industrial societies must "create the need for buying the goods that must be profitably sold." As he says:

No matter how much such needs may have become the individual's own, reproduced and fortified by the conditions of his existence; no matter how much he identifies himself with them and finds himself in their satisfaction, they continue to be what they were from the beginning - products of a society whose dominant interest demands repression. ${ }^{10}$

The true or "vital" needs, "nourishment, clothing, lodging at the attainable level of culture"11 are "the prerequisite for the realization of all needs," but the superimposed false needs manifest in the same fashion as the vital needs for the individuals in a one-dimensional society, mixing and melding into an indiscernible mess as the social structure of the advanced society replaces a wholly autonomous individual with the heteronomy born of the society's need to perpetuate itself through its production of items and, in so doing, the production of false needs for items that they naturally, vitally, truly would otherwise not need at all. The significance of distinguishing the false needs from the true is quite profound. As Marcuse notes, if our needs, our desires, our very instincts are superimposed upon us, and this superimposition is actively perpetrated by a structured society bent on perpetuating itself, the individual loses his freedom of autonomous self-development. Further, the individual loses sight of what is lost, as a type of artificial euphoria permeates the life of the individual within the advanced industrial society. False needs supplant true needs but masquerade as true needs and efficacy for critique is

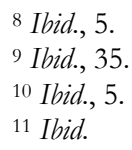




\section{A CRITICAL PRAGMATISM}

compromised. As long as individuals "are kept incapable of being autonomous, as long as they are indoctrinated and manipulated (down to their very instincts), their answer to this question" of which needs are true and which needs are false "cannot be taken as their own."12 Thus, Marcuse asks "how can people who have been the object of effective domination by themselves create the conditions of freedom?" 13

The structure of the advanced industrial society is totalitarian, selfcontained and self-perpetuating by the very conditions of its structure. "Totalitarian," at first glance, seems an odd choice of term to describe a society that provides a certain type of liberty (indeed, prides itself on a certain type of liberty) and induces, at least, a pleasant sort of euphoria in its citizens. This paradox of advanced industrial societies further obfuscates the irrationality of the nature of this society as it offers both satisfaction and a certain form of apparent liberty while remaining totalitarian in the structures that perpetuate themselves at the cost of human autonomy.

By virtue of the way it has organized its technological base, contemporary industrial society tends to be totalitarian. For 'totalitarian' is not only a terroristic political coordination of society, but also a nonterroristic economic-technical coordination which operates through the manipulation of needs by vested interests. ${ }^{14}$

The coordination of commercial needs to perpetuate its growth and financial gain is coupled with the technological era's advanced forms of information and advertising proliferation allowing it to completely inundate the individual with whatever product or ideology it deems profitable to advance. "It thus precludes the emergence of an effective opposition against the whole." 15 It is in this sense that the advanced industrial society, despite its emphasis on some form of "freedom," and despite the ubiquitous euphoric indulges it affords its citizens, can still be considered "totalitarian," for the structures in place to perpetuate the system (the structures themselves) are such that they flatten potentiality and streamline development towards their own ends, subsuming or repelling any possible opposition. This is what Marcuse means when he claims the advanced industrial society is "onedimensional."

The products indoctrinate and manipulate; they promote a false consciousness which is immune against its falsehood. And as these beneficial products become available to more individuals in more social classes, the indoctrination they carry ceases to be publicity; it

\footnotetext{
12 Ibid., 6.

13 Ibid.

14 Ibid., 3.

15 Ibid.
} 
becomes a way of life. It is a good way of life - much better than before - and as a good way of life, it militates against qualitative change. Thus emerges a pattern of onedimensional thought and behavior in which ideas, aspirations, and objectives that, by their content, transcend the established universe of discourse and action are either repelled or reduced to the terms of this universe. ${ }^{16}$

The vested interests, the "administrative-bureaucratic apparatus which organizes, manages, and stabilizes capitalist society,"17 utilize the advanced forms of technology and its proliferation of advertising and media control to "invade" the individual's "private space" until it is "whittled down by technological reality." 18 Thus proliferated, it is capable of advancing whatever agenda it deems most profitable, both in a literal sense, and in the sense of the "profitability" of perpetuating its own structure. The creation of false needs is a key component to this agenda, creating needs for products for the sole purpose of profiting from their sale. In creating needs that the vested interests then fulfill a euphoria overcomes the individual whose "needs" have been fulfilled, a type of drugged-stupor, like an addict receiving a fix (a false need for the drug is fulfilled by the otherwise-unnecessary fix resulting in a temporary, but very real, euphoria). This "drugging rhythm" 19 promotes a type of "onedimensional thought" that is "systematically promoted by the makers of politics and their purveyors of mass information. Their universe of discourse is populated by self-validating hypotheses which, incessantly and monopolistically repeated, become hypnotic definitions or dictations." ${ }^{20} \mathrm{Key}$, too, is the society's ability to "militate against qualitative change" by flattening and reducing all content, material or idealistic, to its own, pre-established universe of discourse, a discourse that, as we've seen, is populated by "selfvalidating hypotheses." Any discourse that cannot be subsumed into this selfvalidating discourse is repelled. Implicitly here (and explicitly elsewhere) is the dissolution of dialectics, of dichotomies, of opposition of any kind. This pivotal point greatly influenced Habermas, inspiring him to abandon the Hegelian-cum-Marxian dialectic as advanced industrial societies dissolve any form of opposition necessary for such dialectical interplay to unfold. Indeed, without opposition, without a multi-dimensionality of opposing universes of discourse, of different potentialities for actualization, of different systems and structures, there is only the closed, heteronymous one-dimensionality of the advanced industrial society.

${ }^{16}$ Ibid., 11.

17 This is Douglas Kellner in his introduction to the second edition of One-Dimensional Man paraphrasing Rufolf Hilferding's Finance Capital (London: Routledge, 1981, originally published 1910).

${ }^{18}$ Ibid., 10.

${ }^{19}$ Ibid., 26.

${ }^{20}$ Ibid., 14. 


\section{A CRITICAL PRAGMATISM}

This sort of "controlled" 21 or "institutionalized desublimation" 22 is nothing more nor less than the complete "conquest and unification of opposites." 23 This "unification of opposites" should not be taken in the Hegelian sense of the dialectic, the realization, that is, of the Absolute or a perfect society. For Marcuse, rather, this unification of opposites is the absorption of any alternative discourse into the structures of the advanced industrial society. The structures in place to perpetuate the agendas of the system effectively take what is "other" or alien to the system and make it part of the system, effectively absorbing alternative discourses into the status quo of the advanced industrial society. The distinction, in fact, between the Hegelian and the Marcusean conception of the unification of opposites is a telling example of precisely why Habermas was influenced to abandon the dialectic of the former. "Artistic alienation," as an example Marcuse invokes, is a positive sort of "sublimation that "creates the images of conditions which are irreconcilable" 24 with the established universe of totalitarian discourse. This form of sublimation creates the sort of opposition that the advanced industrial society would attempt to flatten into its one-dimensionality, a sort of opposition that is "edifying and useful" 25 in creating the type of potential alternatives that allow for a more natural sort of growth and progress by offering alternatives that are not subsumed into the totalizing system. It creates the type of opposition that engenders struggle and demands engagement, perhaps even overcoming, not through the desublimation of alternatives into a pre-established universe of tautological discourse and onedimensionality, but something wholly external to the system. Without this threat of the entirely "other," without this threat from outside the established system, there is only the one-dimensionality of the system itself, and whatever options are presented therein are compatible with the totalizing system and, in so being, are only "options" in a very nominal sense without real efficacy.

In the mental apparatus, the tension between that which is desired and that which is permitted seems considerably lowered, and the Reality Principle no longer seems to require a sweeping and painful transformation of instinctual needs. The individual must adapt himself to a world which does not seem to demand the denial of his innermost needs - a world which is not essentially hostile. The organism is thus being preconditioned for the spontaneous acceptance of what is offered. Inasmuch as the greater liberty involves a contraction rather than extension and development of instinctual needs, it works

\footnotetext{
${ }^{21}$ Ibid., 77.

22 Ibid., 79.

${ }^{23}$ Ibid., 71.

${ }^{24}$ Ibid., 72.

25 Ibid.
} 


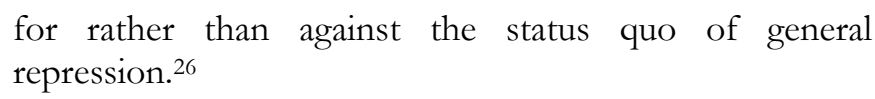

The dissolution of opposition appears, in many respects, to be a positive effect of technologically advanced societies but, again, only so far as it supplants true happiness and freedom with a type of euphoria. The system's dissolution of opposites through this controlled, institutionalized desublimation, flattens real possibilities and reduces them to mere options, preestablished, within a pre-established universe of discourse that is, itself, comprised only of tautological hypotheses that are self-perpetuating. Real difference is supplanted for false difference, real needs for false needs, real freedom for media-controlled heteronomy, real potential for growth and development for the pre-structured arenas where growth and development only come in pre-established frameworks and through pre-established terms. And always the latter masquerading as the former thus effectively denying the possibility for real critique as the problems are obfuscated and euphoria pervades.

Institutionalized desublimation thus appears to be an aspect of the 'conquest of transcendence' achieved by the one-dimensional society. Just as this society tends to reduce, and even absorb opposition...in the realm of political and higher culture, so it does in the instinctual sphere. The result is the atrophy of the mental organs for grasping the contradictions and the alternatives. ${ }^{27}$

Our project here is not merely to analyze Marcuse's account of onedimensional society, but to read it through social psychology, that is, to give an account for what effect one-dimensional society has on individual human growth and development. Herein lies Marcuse's own social psychology, for at the heart of all social psychological theories are the ways in which our instincts are coordinating into character-forming habits that regulate, and are regulated by, our conscious actions, thoughts and decisions. Here we see the "atrophy" of the mental faculties and the undeniable influence that one-dimensional society has on instinctual development. We've seen this implicitly already, in the supplanting of true or "vital" needs for false ones as an internal movement, needs that are both "superimposed" yet well up within us and dictate not only actions and decisions, but also create the forum for the euphoria that perpetuates the structures that superimposed those needs to begin with.

Up to this point, we've explored the some of the reasons why advanced industrial societies find it beneficial to instill false needs in their citizens. For one thing, they must "create the need for buying the goods that must be

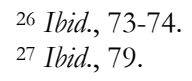




\section{A CRITICAL PRAGMATISM}

profitably sold" 28 especially if those goods have no practical value or, indeed, no value at all save for the very fact that they are desired. Further, if the vested interests can manipulate human needs and desires, it will be all the easier for them to perpetuate their respective agendas and allow the structures of society that sustain them to remain viable. In order to do this, as we've seen, false needs and desires must be artificially created. However, we have not yet fully plumbed the depths of precisely how invasive this is and what the true detriment is to human character.

It is a social psychology that Marcuse is providing in One-Dimensional Man, a project he is picking up from where Marx seemed to leave off. There were two primary aspects of the transition from capitalism to communism that Marx imagined. The first, the breakdown of the capitalistic system, he went into at length. The second, the change in consciousness of the proleriat, Marx did not account for as thoroughly as he did the other. Indeed, commentators like Alasdair Macintyre suggest that so little was said about the growth of political consciousness in the working class that Marx failed to provide an adequate social psychology, a failure that, he contends, prompted Marcuse to pick up where Marx, effectively, left off. ${ }^{29}$

"When the Marxist script for the world drama required a European working class to emerge as the agent of historical change, the working class turned out to be quiescent and helpless." 30 The question becomes, of course, what happened to the individuals in these modern societies when the moment came for action, for disruption, for revolutionary change, there was only passivity and acquiescence? As Jeffry Ocay rightly notes, instead of the transition from capitalism to socialism, what happened instead was the "integration of the proleteriat into the status quo" and "the absence of a revolutionary agent for progressive social change." 31 What cognitive effect did these societies have over their citizens to quell revolution not exclusively through external means, but primarily through effectively debilitating the conscious desire for change? "The suggestion, therefore, that under capitalism men are dominated and exploited not merely by external oppressors, by those who own and those who rule, but by forms of consciousness which prevent them from liberating themselves." 32 It is no exaggeration to say that the bulk of One-Dimensional Man was an investigation into this very phenomenon, the social psychology at the heart of advanced industrial societies whose technological proliferation has so whittled down the individual's private space that the individual is no longer capable (perhaps, no longer willing) to envision alternative structures, societies and discourses. "The fundamental thesis of One-Dimensional Man is that the technology of advanced industrial societies has

\footnotetext{
${ }^{28}$ Ibid., 35.

${ }_{29}$ Alisdair Macintyre, Herbert Marcuse: An Exposition and a Polemic (New York: The Viking Press, 1970), 45.

${ }^{30}$ Ibid., 46.

${ }^{31}$ Jeffry Ocay, "Eroticizing Marx, Revolutionizing Freud: Marcuse’s Psychoanalytic Turn," in Kritike, 3:1 (June 2009), 11.

32 Ibid.
} 
enabled them to eliminate conflict by assimilating all those who in earlier forms of social order provided either voices or forces of dissent." ${ }_{3}$ The individual has "become a willing subject" 34 of the technological proliferation that has granted him innumerable minor pleasures that satisfy the needs that often the technology, itself, created. A totalizing, insular system of self-perpetuation that has so deeply penetrated into the daily needs and desires of its citizens that their willingness to even envision alternative discourses is compromised if not outright dissolved. This is the annihilation of what Marcuse called "negative thinking" and without negative thinking there can be no Great Refusal.

The inner, private space of the individual "has been invaded and whittled down by technological reality. Mass production and mass distribution claim the entire individual." 35 It is in this realm of the inner, private space that negative thinking is capable of taking place, that is, the envisioning of entirely alternative modes of discourse and society. "Naming the 'things that are absent' is breaking the spell of the things that are, it is the ingression of a different order of things into the established one." 36 As Kellner notes, negative thinking "'negates' existing forms of thought and reality from the perspective of higher possibilities." 37

The eradication of negative thinking is a paradigmatic symptom of one-dimensional thought. Without the ability to envision alternative discourses, perhaps even without the will to do so, the advanced industrial society effectively negates the possibility of negation, killing the potential to refute the current status quo and strive towards a potential alternative discourse. This negates the possibility of what Marcuse called the "Great Refusal,"38 "the protest against that which is." 39 Without a Great Refusal resulting from negative thinking, the advanced industrial society successfully perpetuates itself and negates the possibility of radical social change.

Profoundly disturbing is the necessity for technological proliferation to penetrate so deeply into the individual consciousness that the ability to envision and will alternative discourses becomes a near impossibility. In order to perpetuate itself, advanced industrial societies have to sedate individual citizens into a state of acquiescence, a proliferation of minor pleasures that can effectively masquerade as true happiness and thus provide no incentive for radical social change. For Marcuse, the result was a conformist, onedimensional, inauthentic ${ }^{40}$ society. As Ocay ${ }^{41}$ notes, it was not sufficient for

33 Macintyre, Herbert Marcuse: An Exposition and a Polemic, 71

${ }^{34}$ Robert Marks, The Meaning of Marcuse (New York: Ballantine Books, 1970), 68

${ }^{35}$ Marcuse, One-Dimensional Man, 10.

${ }^{36}$ Ibid., 68.

${ }^{37}$ Ibid., xiv.

38 Douglas Kellner, Herbert Marcuse and the Crisis of Marxism (Berkeley: University of California Press, 1984). “The term 'Great Refusal' was inspired by Andre Breton, who defended the total refusal of the institutions, values and way of life in bourgeois society. It is this notion of individualistic refusal and revolt that characterizes Marcuse's political conception in ODM," 279. ${ }^{39}$ Marcuse, One-Dimensional Man, 63.

${ }^{40} \mathrm{I}$ mean this in the Heideggerian sense. Douglas Kellner, in his Hertbert Marcuse and the Crisis of Marxism, describes Heidegger's influence on Marcuse in great detail, especially the 
Marcuse's revitalization of Marx to rely solely upon Heidegger and Hegel. To fully account for this extreme sort of conformist society, he had to likewise draw upon Freud to establish a dynamic social psychology that could fully articulate what Marcuse saw as symptomatic of a one-dimensional individual and this acquiescence to the status quo which negates the possibility of radical social change.

The complacency Marcuse saw as a reasonable explanation for the failure of the historical moment of transition from capitalism to socialism was one of the primary foci of his Eros and Civilization, picked up again in OneDimensional Man. ${ }^{42}$ Complacency, Marcuse argued, was fundamentally an issue of desire satisfaction, namely, that without the desire for something more than what the current status quo was offering its citizens, the citizens had no viable reason to engage in the negative thinking that could lead to a Great Refusal and the onset of radical social change. "If the individuals are satisfied to the point of happiness with the goods and services handed down to them by the administration... and if the individuals are pre-conditioned so that the satisfying goods also include thoughts, feelings, aspirations," 43 what need, then, is there for them to imagine a radical alternative?

Thus, in order to understand the complacency at the heart of the problem as Marcuse saw it, he turned to Freud's theory of instincts to flesh out his own social psychology that had already engaged this notion of false, artificially imposed needs, drugging rhythms, and the invasive technological proliferation into the most intimate, inner spaces of the citizens.

"According to Freud, the history of man is the history of repression." 44 The basic instincts of Eros and Thanatos are fundamental, driving forces in human character. Eros, the life-instincts, maintain the "elemental goal" of the "preservation of life" 45 and Thanatos, the destructive, death instincts, "whose primary goal is the destruction of life, are the two mechanisms immanent within the human psyche that man uses in the process of releasing tension." 46 Through the immediate satisfaction of sexual desires and destruction, Eros and Thanatos combine to form what Freud called the "pleasure principle." Freud famously notes, however, that the uncontrolled satisfaction of the pleasure principle would have devastating repercussions, as

\footnotetext{
juxtaposition of the "one-dimensional" and the "authentic" individual. See p. 236 for a chart comparing the two types of individuality.

41 Ocay, "Eroticizing Marx, Revolutionizing Freud: Marcuse’s Psychoanalytic Turn,"

11.

42 Ocay, "Eroticizing Marx, Revolutionizing Freud: Marcuse's Psychoanalytic Turn," "Marcuse's intention here is clear: to explain why the transition from capitalism to socialism did not happen, why...the revolutionary class had been dissolved and became conformist," 12 .

${ }^{43}$ Marcuse, One-Dimensional Man, 50.

${ }^{44}$ Herbert Marcuse, Eros and Civilization (Boston: The Beacon Press, 1966), 11.

45 Ocay, "Eroticizing Marx, Revolutionizing Freud: Marcuse’s Psychoanalytic Turn,"

12.$$
46 \text { Ibid. }
$$ 
Marcuse notes, "the uncontrolled Eros is just as fatal as his deadly counterpart, the death instinct." 47

Beyond the self-annihilating potential of uncontrolled instinctual desires, the pleasure principle, left unchecked, is incompatible with civilization. "Left free to pursue their natural objectives, the basic instincts of man would be incompatible with all lasting association and preservation." 48 The transformation of animal man to civilized human being takes place when the instincts of the pleasure principle are effectively repressed and redirected by what Freud termed the "reality principle." 49 This reality principle, maintaining the realistic avenues of tension alleviation and desire satisfaction in a civilized community, include delayed satisfaction rather than immediate, toil instead of play, security instead of a complete absence of repression.

As Robert Marks, "The reality principle materialized as a system of institutions. The domination of the reality principle over the pleasure principle, however, is never complete. Civilization does not once and for all terminate the state of nature." 50 The reality principle kept in check the pleasure principle's potentiality for self-destruction and made for a civil environment in which individuals could live alongside one another without the fear of Eros and Thanatos running rampant. Further, the reality principle was useful in the face of the unquestionable reality of scarcity, or "ananke." Simply, "there is not enough of the world's goods to go around; pleasure does not produce food or shelter' work is unavoidable." 51 One of the best articulations of this phenomenon of scarcity can be found in Jean-Paul Sartre's Critique of Dialectical Reason in which he notes that men are "dominated by necessity and scarcity," 52 and its cold reality effects every interaction between them. Indeed, with the necessary supplanting of joy and play for work and toil, the reality principle, on the one hand, helped manage the objective fact of ananke. On the other hand, scarcity is, itself, a factor that has a bearing upon repression, just as the institutionalized form of the reality principle that aids in managing it.

Macintyre argues that "Marcuse takes it to be true that a certain basic repression and asceticism were necessary to build civilization because of economic scarcity and the work necessary to overcome it." ${ }_{33}$ However, in advanced industrial societies the relatively complex movement from pleasure principle to reality principle is insufficient to account for what takes place on the instinctual level of its citizens. In order to account for the impact technological proliferation has on the citizens of advanced industrial societies, Marcuse introduces two new terms: surplus repression and the performance

\footnotetext{
${ }^{47}$ Marcuse, Eros and Civilization, 11.

48 Ibid.

49 For a concise account of this transformation, see Marcuse's chart in Eros and Civilization, 12 of this edition.

${ }^{50}$ Marks, The Meaning of Marcuse, 43.

${ }^{51}$ Ibid., 44.

${ }^{52}$ Jean-Paul Sartre, The Critique of Dialectical Reason, trans. Alan Sheridan-Smith (New York: Verso, 2004), 37.

${ }^{53}$ Macintyre, Herbert Marcuse: An Exposition and a Polemic, 48.
} 


\section{A CRITICAL PRAGMATISM}

principle as an augmentation of the reality principle. These are key to understanding Marcuse's social psychology.

"Surplus repression denotes the restrictions on behavior resulting from social domination, and is distinguished from the repression necessary for the perpetuation of the human race - basic repression." 54 As Macintyre notes:

The form of the distribution of work have always been imposed upon me, and the forms of repression necessary to maintain them represent an overplus beyond what is necessary for civilization. Furthermore, as technical and material progress removes the obstacles which scarcity placed in the path of civilized development, repression is more and more surplus to the task of maintain civilization. ${ }^{55}$

As such, the reality principle is insufficient a concept to account for the phenomenon of advanced industrial society's ability to overcome many of the obstacles created by scarcity.

To claim that it is the reality principle which demands repression Marcuse retorts that we confused the demands of the reality principle with the demands which some particular form of social domination seeks to impose in the name of reality. That we should perform our social tasks in an allotted order and hierarchy is not a prescription of reality as such; the principle embodied in this prescription is what Marcuse calls the performance principle. ${ }^{56}$

The performance principle is Marcuse's counterpart for Freud's reality principle in the advanced industrial society. Even in a liberated society, as envisioned by Marcuse, there will always be some need "for a basic reality principle and necessary repressions" 57 but in our modern societies, the advanced technological proliferation has altered truly "necessary" forms and degrees of repression. For Marcuse, human history can be divided into two epochs from a Freudian perspective. Up through the modern age, a certain amount of repression and social domination was necessary to confront ananke, this scarcity, and provide the technological substructures required for abundance. But in the second phase, the age of the advanced in industrial

\footnotetext{
${ }^{54}$ Marks, The Meaning of Marcuse, 45.

55 Macintyre, Herbert Marcuse: An Exposition and a Polemic, 48-49.

${ }^{56}$ Ibid., 49.

${ }^{57}$ Marks, The Meaning of Marcuse, 45.
} 
society, the repression of the pleasure principle has become needlessly repressive, excessively so, a "surplus repression." 58

The effect advanced industrial societies have on basic human instincts is quite profound. As he says in Eros and Civilization:

However, the psychoanalytic interpretation reveals that the reality principle enforces a change not only in the form and timing of pleasure but in its very substance. The adjustment of pleasure to the reality principle implies the subjugation and diversion of the destructive force of instinctual gratification, of its incompatibility with the established societal norms and relations, and, by that token, implies the transubstantiation of pleasure itself. ${ }^{59}$

Especially in advanced industrial societies, in which there is a surplus of repression, in which the reality principle is transmogrified into the performance principle. Because the societal structures are forwarding a specific, constructed reality, pleasure, itself, has taken on a new form. Further, the avenues through which to release the tensions that the basic instincts of the pleasure principle demand are tailor-made to allow the controlled release of these tensions and the controlled satisfaction of pleasures that the structures, themselves, created. False needs, in short, imposed upon individuals in advanced industrial society, reflect the transmogrified pleasures Marcuse originally discussed in Eros and Civilization. Further, precisely because advanced industrial societies create the means by which these needs can be met, effectively, the human inner space is so whittled down by technological proliferation that the aims of Eros are artificially constructed and just as artificially satisfied. This is the "euphoria" he speaks of in One-Dimensional Man, the "drugging rhythm" that effectively negates the need for negative thinking and abolishes any chance for a Great Refusal that would herald in an age of radical social change. Everything becomes insulated within the totalizing structures: from the basic pleasures through their satisfaction, requiring no need for an appeal to alternative discourses, no need for change, no need for negative thinking, and, ultimately, no authentic individuality. All that remains is the heteronomous, one-dimensional man, who from the basic instincts up, is conditioned by the technological proliferation of his society.

This social psychology of repression has vast moral implications, as well, especially in the tradition of critical theory. Theodor Adorno, in his second lecture on the Problems of Moral Philosophy delivered on May 9th, 1963, implicitly touches upon some of the moral problems that appear to be a natural consequence of too rigid and too all-subsuming a structured universe of discourse in an advanced industrial society. He says that "the concept of

${ }^{58}$ For a full account of these two historical phases, see Macintyre, Herbert Marcuse: $A n$ Exposition and a Polemic, 49.

${ }^{59}$ Marcuse, Eros and Civilization, 13. 


\section{A CRITICAL PRAGMATISM}

morality is problematic above all because it has its origin in 'mores,' in other words, because it postulates a harmony between the public customs in a country and the moral, ethically correct behavior, the moral life of the individual." "60 Adorno rejects a more Hegelian read of "the substantial nature of the ethical" as a "belief that the norms of the good are directly anchored and guaranteed in the life of an existing community" as a belief that "can no longer be assumed today." 61 Instead, and unsurprisingly, Adorno advances a far more Kantian read of morality, tension and sustained opposition rather than harmony and synthesis,

...a realm which is concerned from the outset with tensions and contradictions, namely with the question of how to bring individual interests and claims to happiness into harmony with some sort of objective norms binding on mankind as a whole. What is problematic about this concept of personality is that these tensions are swept aside, spirited away, and that it looks as if all you really need to lead the good life is to be yourself and to be identical with yourself. ${ }^{62}$

Like Marcuse's account of sublimation and desublimation, Adorno maintains that "if humanity has any meaning at all, it must consist in the discovery that human beings are not identical with their immediate existence as the creatures of nature" 63 thereby maintaining the necessity of a type of sublimation, something that transcends, by its content, the established universe of discourse. As Marcuse himself notes, "desublimation" is the "replacing mediated by immediate gratification." 64 The realization of non-identity is the sublimation of realms of possibility beyond those advanced and permitted within the established universe of discourse. It offers the opposition required for genuine, authentic freedom and human development, here, too, in the realm of morality.

Moral questions have always arisen when moral norms of behavior have ceased to be self-evident and unquestioned in the life of the community. Thus morality as a theoretical discipline...arises at the precise moment... when the customs and usages that obtain and have been generally accepted within the life of a people have lost their immediate authority. ${ }^{65}$

60 Theodor Adorno, Problems of Moral Philosophy, trans. by Rodney Livingstone (Stanford: The Stanford University Press, 2001), 12.

${ }^{61}$ Ibid.

${ }^{62}$ Ibid., 14.

${ }^{63}$ Ibid., 15.

${ }^{64}$ Ibid., 72.

${ }^{65}$ Ibid., 16. 
One-dimensional, overly stratified advanced industrial societies, in their need to self-perpetuate, to flatten possibilities by dissolving oppositions, run the risk of stagnating moral development or, perhaps more specifically, they run the risk of "repelling" the type of moral alternatives that a community might desperately need. Adorno appropriately invokes the example of Nazi Germany:

We must add that it is not uncommon for the customs of a nation to assume the form of what the Nazis called Brauchtum [usage, custom], and for mores to persist even though the consciousness of individuals and the critical labor of the intellect are no longer in tune with them. But the moment such customs continue to assert themselves in the face of a confrontation with liberated, autonomous reflection, it ceases to be possible to regard them as the vestiges of things that are old, good and true because they then assume the features of something poisoned and evil. ${ }^{66}$

Customs that are overly stratified and reinforced by the mandate of a one-dimensional society repel the alternative frameworks necessary to supply the type of opposition needed for perspective, comparison, and the tension that instigates growth and development. It is only when tensions are maintained, despite the totalitarian nature of such a society, that autonomous reflection bears down upon custom in dialectical opposition, can true progress be made.

Ninety years before Adorno's lectures, C.S. Peirce called this stratified, totalitarian structure as a type of society that utilizes "the method of authority" 67 in his seminal essay, "The Fixation of Belief." Although much of critical theory appears hostile to a certain form of pragmatism (for reasons we sadly have no time to engage here), I suggest that pragmatism, intimately bound with social psychology, ${ }^{68}$ given the proper critical turn, maintains not only the same type of critique of advanced industrial societies as forwarded by Marcuse, but likewise offers a "destratified" template for human development in the face of an overly stratified social structure. Here, then, we turn to a critical pragmatism.

${ }^{66} \mathrm{Ibid} ., 17$.

${ }^{67}$ C.S. Peirce, Philosophical Writings of Peirce, ed. by Justus Buchler (New York: Dover Publications, Inc., 1955), 14.

${ }^{68}$ Beyond Peirce's "Fixation of Belief," see James' Principles of Psychology and especially Dewey's Human Nature and Conduct as seminal texts in the history of social psychology. 


\section{Part II: Critical and Naive Pragmatism}

As a precursor to the contributions to psychology by William James and the social psychology of John Dewey, in his 1877 essay "The Fixation of Belief," Peirce explores the relationship between doubt and belief in human consciousness and frames this exploration in terms of a movement between the former towards the latter, a cyclical movement, in fact, based upon three specific moments. Implicitly, and what Dewey will eventually excavate for his social psychology and make profoundly explicit, is that this movement from doubt to belief is not a "vicious cycle" but, rather, a type of "virtuous circuit," in which the oscillation between the one and the other does not take place in a vacuum devoid of progress but, rather, forms the very foundation of human progress, growth and development. Pertinent to our investigation here, Peirce's exploration of the different methods for "fixing belief" articulate how an individual operates in order to establish belief, abolish doubt, within societies that allow the individual to do so freely, and societies which establish fixed, structured frameworks that artificially stagnate and mutate what should otherwise be a free, autonomous exploration.

"That which determines us...to draw one inference rather than another, is some habit of mind, whether it be constituted or acquired." ${ }^{69}$ How an individual engages the world is in large part determined by the habits of mind that that individual has acquired, a point taken up by Dewey later on in his Human Nature and Conduct. Like all habits, habits of mind can be good or bad and the quality of the habit is determined by, on one hand, the efficacy of the resulting activities and how much it resonates with the encountered world and, on the other, the manner by which those habits were acquired in the first place. A certain degree of efficacy, repeated success when ideas are brought to bear upon varying, protean situations, produces a state of belief in the individual that their ideas are the right ideas to have and (in classic pragmatic terms) "work" efficiently to solve problems and produce results conducive to the perpetuation of the organism in an often hostile, protean environment. Opposed to this state of belief is a state of doubt, a state instigated by the onset of a problematic situation defined as that which deviates from the normal efficacy of the applied habit of mind. "Doubt... stimulates us to inquiry until it is destroyed" such that "the irritation of doubt is the...motive for the struggle to attain belief." 70 We begin to see a proto-Marcusean argument against desublimation here through the subtle implication that without opposition, that is, without problematic situations resulting in a state of doubt in the conscious subject, there could be no intellectual progress but, rather, eternal stagnation in an artificially continuous state of belief. "Doubt is an uneasy and dissatisfied state from which we struggle to free ourselves and pass into the state of belief; while the latter is a calm and satisfactory state which we do not wish to

\footnotetext{
${ }^{69}$ Peirce, Philosophical Writings of Peirce, 8.

${ }^{70}$ Ibid., 10.
} 
avoid." 71 We strive to be in a state of belief, Peirce argues, but we must never strive so "tenaciously" that we lose our ability to engage in unimpeded inquiry.

Precisely because doubt is the result of a problematic situation, individuals can, indeed, quite often do, linger in the "calm and satisfactory" state of belief far longer than is reasonable. This "instinctive dislike of an undecided mind, exaggerated into a vague dread of doubt, makes men cling spasmodically to the views they already take." 72 This can prove highly inconvenient "as if a man should resolutely continue to believe that fire would not burn him" "73 when all evidence is to the contrary and yet this can still be a more appealing alternative than to plunge head-long into a state of doubt and uncertainty. "When an ostrich buries its head in the sand as danger approaches, it very likely takes the happiest course. It hides from the danger, and then calmly says there is no danger; and, if it feels perfectly sure there is none, why should it raise its head to see?" 74 This method of fixing one's belief he called "the method of tenacity" 75 and, clearly, he rejects this method as highly inefficient and deeply problematic.

Whatever habits of mind were cultivated in the individual to produce such a method of fixing belief, be they self-constituted, acquired from an external source or, more likely, some combination of the two, are clearly not the most successful habits of mind. The habits of mind involved are necessarily "bad" habits for the method they produce for fixing belief "will be unable to hold its ground in practice...the man who adopts it will find that other men think differently from him, and it will be apt to occur to him, in some saner moment, that their opinions are quite as good as his own, and this will shake his confidence in his belief"76thereby not only proving unproductive in practice but, ultimately, leading to the state of doubt that that individual was so desperately seeking to avoid in the first place.

Peirce then suggests, for the sake of argument, that the forum for fixing belief be shifted from the individual to the state for "unless we make ourselves hermits, we shall necessarily influence each other's opinions; so that the problem becomes how to fix belief, not in the individual merely, but in the community." 77 It is here, in what Peirce calls "the method of authority"78 that we see a clear precursor to the tradition of critical theory that Marcuse exemplifies in One-Dimensional Man. So that individuals with conflicting beliefs cannot encounter one another with dialectically opposed theories that will, likely, instill a state of doubt in either or both individuals, the state superimposes a universal system of belief, a uniform universe of discourse, for all individuals within that society, negating the possibility that two individuals

\footnotetext{
${ }^{71}$ Ibid.

${ }^{72}$ Ibid., 11-12

${ }^{73}$ Ibid., 12.

${ }^{74}$ Ibid.

${ }^{75}$ Ibid.

76 Ibid.

77 Ibid., 13.

${ }^{78}$ Ibid., 15.
} 


\section{A CRITICAL PRAGMATISM}

could have wildly conflicting states of belief. And should two individuals encounter one another within such a state of authority with what appear to be conflicting ideologies they will not, in fact, be born of genuine difference but, rather, mere opinions, differing in "texture" rather than kind, both of which supported by, and reifying, the state of authority in which they operate.

Let an institution be created which shall have for its object to keep correct doctrines before the attention of the people, to reiterate them perpetually, and to teach them to the young; having at the same time power to prevent contrary doctrines from being taught, advocated or expressed. Let all possible causes of a change of mind be removed from men's apprehensions. Let them be kept ignorant, lest they should learn of some reason to think otherwise than they do. ${ }^{79}$

The resonance with Marcuse is poignant, especially when one considers the overly sardonic, almost hostile manner with which Peirce rejects this second possibility for fixing belief. We see here shades of the advanced industrial society's creation of an insular, self-perpetuating structure that repels opposition, subsuming it or rejecting it outright through institutionalized desublimation. Peirce notes that this method has been used often and to great success, in "Egypt and in Europe" 80 and, though he wrote before the rise of Nazi Germany, I maintain, along with Adorno, Peirce would have invoked that regime as a clear example of the type of authoritarian structure that exemplifies this method of fixing belief.

Both the method of tenacity and the method of authority must be rejected for both oppose the freedom of open-ended inquiry, a concept that clearly resonates with the goals of critical theory. The former is self-imposed ignorance in which the individual clings tenaciously to the safe state of belief and avoids the type of problematic situations that result in a state of doubt at all costs, thus narrowing his own opportunities for development. The latter is more in keeping with Marcuse's critique of advanced industrial society in which the society, itself, imposes upon its citizens a method for fixing belief, namely, by assigning whatever truth, whatever universe of discourse, is most profitable for the society in question to the exclusion of all other possibilities, thereby barricading itself from the opposition external to the established system that would allow for genuine freedom and development. Rather, Peirce advocates a third method, the scientific method of inquiry, in which inquiry is left "unimpeded" within a society that allows "men, conversing together and regarding matters in different lights" to "gradually develop beliefs in harmony with natural causes." 81 The impediments to free, open-ended inquiry as found

\footnotetext{
${ }^{79}$ Ibid., 13.

${ }^{80}$ Ibid., 14.

${ }^{81}$ Ibid., 15.
} 
in the method of authority and in Marcuse's advanced industrial society are dissolved. Individuals are not kept in isolation from one another but, rather, encouraged to communicate with one another, ${ }^{82}$ bringing to bear different beliefs, from "different lights" and bringing these varying beliefs, in turn, to bear upon the natural world. Implicitly, Peirce is advocating a method that does not avoid problematic situations and the onset of doubt, but, rather, and this is the key point, encourages it.

The movement of doubt to belief does not, as we've said, take place in a vacuum but, rather, forms the very substructure of individual development. Peirce expresses this movement in three stages, namely, (a) a state of belief, followed by (b) the onset of a problematic situation and a state of doubt, met with (c) the onset of inquiry into the nature of the problem and resolution leading to, again, a state of belief. But, just as it is with his semiotics of firstness, secondness and thirdness, as well as his phenomenology, ${ }^{83}$ this second state of belief is necessarily different from the first state of belief. Not only different but, necessarily, more advanced, for it has incorporated into itself the previous state of belief as well as the problematic situation which dissolved it into a state of doubt. The second state of belief, the new state of belief, is forged from an understanding of the misapprehensions of the previous state of belief and the understanding of the problem that dissolved it. This is, for Peirce, and for his pragmatic successors, the very heart of individual human development and the genesis for all pragmatic theories of education. Dewey's social psychology adapted this triadic movement in terms of impulses and habits, and how raw, innate impulses, tested by problematic situations, coalesce into fixed habits that determine character and regulate behavior.

Thus, we can see clearly how the structures of advanced industrial societies reflect the type of method of authority expounded by Peirce and the effect they have on individual, human development. By dissolving opposition through institutionalized, controlled desublimation and imposing, by negating any sustained dialectical tension, the problematic situations that would necessitate genuine, authentic doubt from outside the structured universe of discourse that would, in turn, necessitate a movement from doubt to belief that moved beyond said universe of discourse, the method of authority and the advanced industrial society negate genuinely free human development.

Now, critical theory has historically demonstrated hostility towards pragmatism for a variety reasons that we, again, do not have time to explore here in any great detail. On the one hand, they may perceive Jamesian

82 Challenging here is Marcuse's overwhelming pessimism at the end of OneDimensional Man in which he contends that as technological proliferation increases, opportunity for genuine resistance (the Great Refusal) decreases. This critical turn for Peirce at least addresses the symptoms of the problem and reflects Peirce's far more optimistic attitude towards radical social change. Indeed, perhaps here, Peirce, in advocating interpersonal communication rather than isolation, reflects a more Sartrean notion of radical social change through a "groupin-fusion" and the dissolution of "seriality" as seen in his Critique of Dialectical Reason. These are necessary conditions for Peirce in order to bring about radical social change if radical social change is a live possibility.

${ }^{83}$ See Peirce's "The Principles of Phenomenology." 


\section{A CRITICAL PRAGMATISM}

pragmatism as a reaction against, but likewise an extension of, the logical positivism (empiricism) that was so prevalent in the first half of the twentieth century. On the other hand, pragmatism, with its emphasis on overcoming problematic situations to reestablish an equilibrium with social and natural environments, might appear, at first glance, to reinforce, rather than tear down, the structures of the advanced industrial society. Without a proper critical turn, pragmatic habit formation, pragmatic problem solving, pragmatic social psychology in general can be a most impressive tool for reestablishing the equilibrium of a nation of citizens with a totalitarian system. The key difference, I maintain, turns on this notion that there is qualitative distinction between differences, opposition and problems internal to a given structure, and differences, opposition and problems that begin from outside a social structure. The institutionalized desublimation of Marcuse's critique accounts for this distinction and can be a useful tool in differentiating between what I will call naïve and critical pragmatic social psychology. I offer the following diagram:

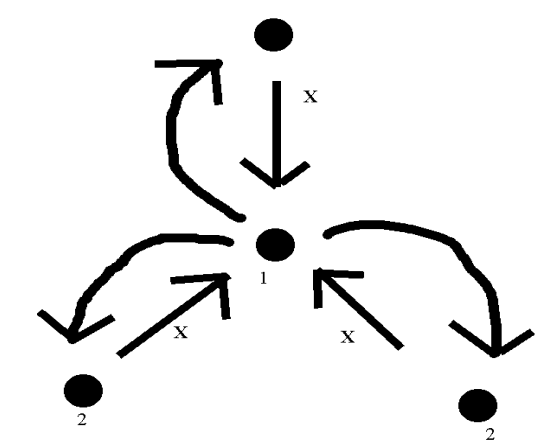

Figure 1 - Critical (Free) Pragmatic Social Psychology

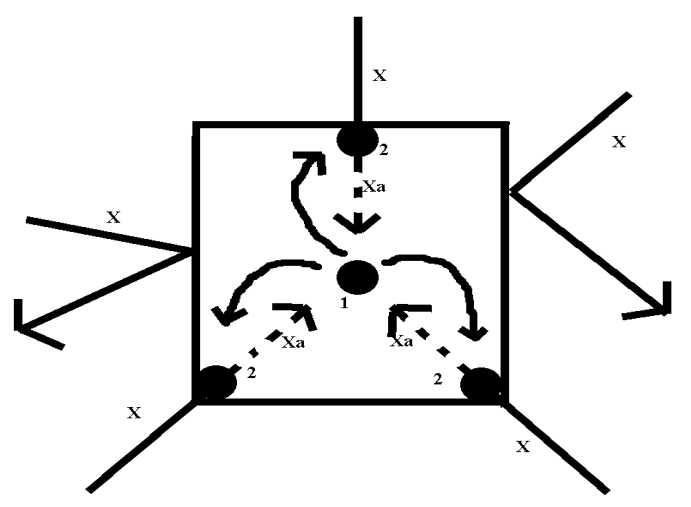

Figure 2 - Naïve (Constrained) Pragmatic Social Psychology 
In figure 1, we see an individual at experience (1) moving to any number of experiences (2) after overcoming a problematic situation. The arrows moving to and from (1) and the various (2) positions indicated both active and passive development, that is, the social and environmental problems (x) either actively assaulting a passive subject, forcing problematic resolution (a flat tire on a deserted road for someone who must now learn to change a tire for the first time) or social and environmental problems (x) being postulated by an active agent who wishes to move to some specific, more advanced experience set (an individual wishing to learn a foreign language, for example, to move from a state of being monolingual to polylingual). The three advanced experience sets (2) are randomly placed to merely represent limitless possibilities for free growth and development, expanding ever outward. In figure 2, on the other hand, we see the pragmatic social psychology of human development as reinforcing the established social order, structure and universe of discourse. Social or environmental problems $(\mathrm{x})$ attempt to invade the social structure but are either desublimated and subsumed into the preestablished universe of discourse or repelled outright. By "desublimation," Marcuse had in mind a sort of "repressive desublimation" in which formerly tabooed customs and practices are granted an immediate sort of satisfaction. They are "desublimated' precisely because the avenues for their satisfaction have been artificially constructed by the societies themselves. Sexually explicit acts, for example, are writ large on billboards and invade every media outlet in the private and public spheres. The acts are no longer sublimated, they've been artificially desublimated by the structures of advanced industrial society as a repressive means of internally providing a euphoric satisfaction to a sexual need. What might otherwise begin as a truly sublimated act or avenue of activity ( $\mathrm{x}$ ) outside the oppressive structures of the system is transformed by the system into an immediate form of satisfaction. This further insulates the system, making it appear as if the satisfactions for these desires are already present in the structures of the society, further negating any need for the negative thinking and imagination of the potentially of alternative modes of discourse to satisfy desires of any kind. Thus, if some of the problems (x) penetrate into the universe of discourse, they are subsumed into that universe of discourse (xa), desublimated, and made a part of the very structure they might have otherwise critiqued. The triadic movement of belief, problemdoubt, inquiry and belief remains the same but limited in its outward mobility, never able to expand beyond the bounds of the established universe of discourse and never able to genuinely, authentically engage with the problems that begin outside that universe of discourse as free, autonomous individuals but only ever as these problems are experienced after being filtered through the structured system. In Deleuzean terms, the growth in figure 1 is destratified and rhizomatic, capable of limitless freedom for autonomous development whereas the growth in figure 2 is highly stratified and arborescent, what development exists is highly contrived, controlled and only ever within the pre- 


\section{A CRITICAL PRAGMATISM}

established structure. The latter is a naïve pragmatism unaware of the social structure within which it operates and, thus, a clear target for critical theorists.

In conclusion, after having enumerated the basic methods by which advanced industrial societies effectively control and stagnate individual human development in Marcuse, and some moral implications of this stagnation in Adorno, I suggest that a certain type of critical pragmatism (a distinction rarely, if ever, made within the tradition itself) can be seen to reflect the type of unconstrained, free, open-ended development that the critical theorists would champion. Left uncriticized, however, pragmatic social development, like the one-dimensional citizens in Marcuse's one-dimensional society, are left unaware that what appears to be free, open-ended development is actually only ever within the constraints of a totalitarian system of domination. Thus, as much as pragmatism might be able to help articulate the social psychology of human development that critical theorists would champion, it can only do so after that very critical theory is applied to their methodology of development to begin with, effectively purifying it from its naïveté.

Department of Philosophy, Duquesne University, United States

\section{References}

Adorno, Theodor, Problems of Moral Philosophy, trans. by Rodney Livingstone (Stanford: Stanford University Press, 2001).

Kellner, Douglas, Herbert Marcuse and the Crisis of Marxism (Berkeley: University of California Press, 1984).

Macintyre, Alisdair, Herbert Marcuse: An Exposition and a Polemic (New York: The Viking Press, 1970).

Marcuse, Herbert, Eros and Civilization (Boston: The Beacon Press, 1966). One-Dimensional Man (Boston: The Beacon Press, 1991).

Marks, Robert, The Meaning of Marcuse (New York: Ballantine Books, 1970).

Okay, Jeffry V., "Eroticizing Marx, Revolutionizing Freud: Marcuse's Psycholanalytic Turn," in Kritike, 3:1 (June 2009).

Peirce, C.S., Philosophical Writings of Peirce, ed. by Justus Buchler (New York: Dover Publications, 1955).

Sartre, Jean-Paul, Critique of Dialectical Reason, trans. by Alan Sheridan-Smith (New York: Verso, 2004). 